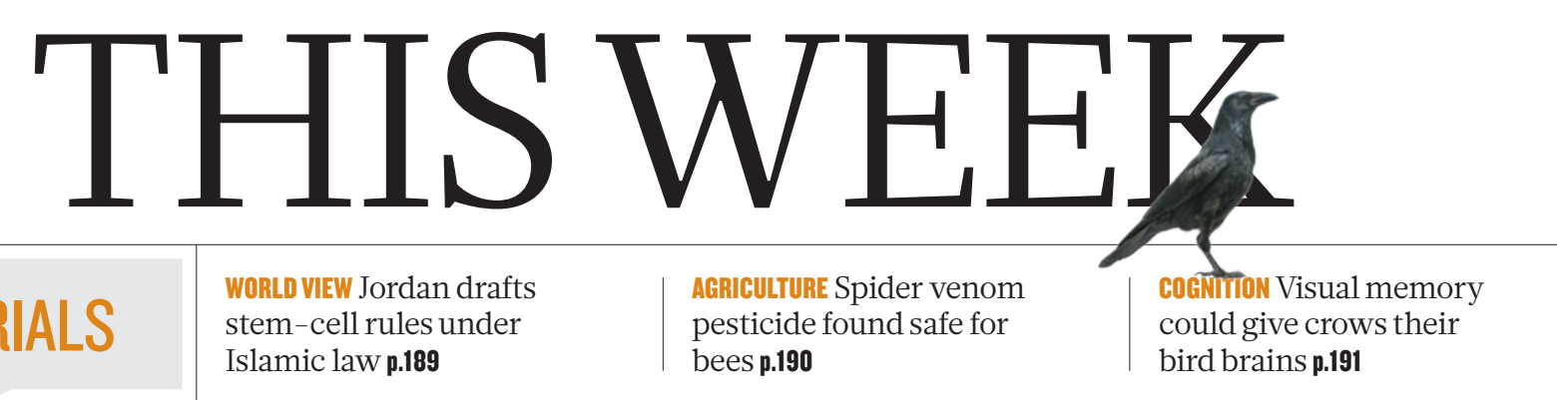

\title{
A growing problem
}

Without careful stewardship, genetically engineered crops will do little to stop the spread of herbicide-resistant weeds.

$\mathrm{P}$ almer pigweed (Amaranthus palmeri) is not a weed to trifle with. It can reach more than 2.5 metres tall, grow more than 6 centimetres a day, produce 600,000 seeds and has a tough, woody stem that can wreck farm equipment that tries to uproot it.

It is also becoming more and more resistant to the popular herbicide glyphosate.

The first such resistant population was confirmed in 2005 in a cotton field in Georgia, and the plant now plagues farmers in at least 23 US states. It is just one of many resistant weeds marching through the world.

The US Environmental Protection Agency (EPA) is trying to learn from the pigweed experience, and wants to limit the damage caused by the latest wave of weed control. It deserves credit and support.

There is broad agreement that the spread of these resistant plants has its roots in the widespread adoption of crops engineered to be resistant to glyphosate. By the time these genetically engineered crops were released in the mid-1990s, farmers had been battling herbicideresistant weeds for decades. But glyphosate was thought to be a particularly challenging herbicide for weeds to overcome. Few cases of resistance had been seen.

That was set to change: by 2012, glyphosate-resistant weeds had infested 25 million hectares of US cropland. They have also appeared in other countries that have embraced glyphosate-tolerant crops, including Australia, Brazil and Argentina. Blanketing crops year after year in the same herbicide is the perfect way to foster resistant weeds.

Chemical companies have come up with a solution: crops engineered to tolerate multiple herbicides. The likelihood of a weed becoming resistant to more than one chemical, they claim, is very small. And, in an eerie echo of the 1990s discussion around glyphosate tolerance, some even point out that one of the other herbicides being targeted - the choline salt of an old chemical called 2,4-D - has been used for decades with little sign of resistance.

It is a flawed argument. Stacking up tolerance traits may delay the appearance of resistant weeds, but probably not for long. Weeds are wily: farmers have already reported some plants that are resistant to more than five herbicides. And with glyphosate-resistant weeds already in many fields, the chances of preventing resistance to another are dropping.

Crops resistant to multiple herbicides could be useful. But scientists are concerned that farmers will rely too heavily on the chemicals, and neglect other ways to combat the resistance threat. Those include using a mixture of herbicides that are specific to a field's invaders, rotating crops and moderate tilling - practices together known as integrated weed management. A farmer making good money in the age of biofuel crop subsidies may be loath to switch to a different crop. And farmers may be hesitant to invest the money needed to properly manage weeds, when their farms could end up infested with weeds from less-assiduous neighbours.

This is where the EPA comes in. In its draft assessment of the

blend of herbicides to be used, it calls for the manufacturer - Dow AgroSciences of Indianapolis, Indiana - to monitor the emergence of resistant weeds and report them to the agency. The EPA will then have the power to impose restrictions on Dow or on the use of the herbicide if it deems this necessary.

The EPA is soliciting comments on the draft assessment from the public until the end of June. It offers sensible precautions, but it could

"The EPA proposes sensible precautions, but it could do much more." - herbicides have limits on how often they can be used for environmental reasons. Such measures would be a sign that regulators and farmers alike have realized the consequences of underestimating the ability of weeds to develop resistance. $\square$

\section{Good practice}

\section{Standardized procedures and analyses should} help to get stem-cell therapies to the clinic.

$\mathrm{U}$ nethical procedures, exploitation and inflated promises, that is what generally makes the headlines - and so it is with regenerative medicine and stem cells. Media reports have left the distinct impression that the research is rather dubious.

First is the long-standing controversy over the source material: human embryos. Research banned by the most powerful man in the world - as US President George W. Bush was when he stopped federal support for such work in 2001 - must be a bit dodgy, right? Then there are the regular reports of companies that are exploiting vulnerable - and often seriously ill - patients with promises of expensive, but unproven, miracle cures.

But behind the headlines is a different story. Scientists doing the systematic research needed to get cellular therapies into the clinic are finally making headway. Trials are now under way for treating an eye disorder called macular degeneration using retinal cells. And a trial using immature glial cells to treat spinal-cord injury has restarted after the company running it pulled out in 2011 (see Nature 510, 18; 2014).

It has taken many years to get to the starting line, but shortcuts are simply not possible, despite charlatan claims. It takes time to 